\title{
Experimental Investigation of Modified Solar Still Productivity under Variable Climatic Conditions
}

\author{
Naseer T. Alwan ${ }^{1,2}$, Sergey E. Shcheklein ${ }^{1}$, Obed M. Ali ${ }^{3 *}$ \\ ${ }^{1}$ Ural Federal University named after the first President of Russia B. N. Yeltsin 19 Mira St., Yekaterinburg 620002, Russia \\ ${ }^{2}$ Kirkuk Technical College, Northern Technical University, 36001 Kirkuk, Iraq \\ ${ }^{3}$ Renewable Energy Research Unit, Northern Technical University, 36001 Kirkuk, Iraq
}

Corresponding Author Email: obedmajeed@ntu.edu.iq

https://doi.org/10.18280/ijdne.150108

Received: 20 January 2020

Accepted: 19 February 2020

\section{Keywords:}

modified solar still, variable climatic conditions, saltwater temperature, single slope, productivity

\begin{abstract}
Conversion of untreated water into drinking water using solar distillation technology can be considered as the most viable methods in the dry climate regions and remote areas. The productivity of solar stills influences by various conditions such as design, operational and environmental conditions. The current paper includes a practical investigation of the effects the climatic conditions on the fresh water production from modified single-slope solar still in Russia. Results analysis showed that the mechanism of heat transfer and mass transfer within the solar still depend on environmental parameters. The heat transfer coefficients have been gradually increased from the early morning after 08:00 am and reached the highest value at the noon then decrease gradually afternoon to reach the lowest value at 20:00 pm. The maximum value of coefficient of heat transfer by evaporation found to be $12.1 \mathrm{~W} / \mathrm{m}^{2}$. $\mathrm{K}$ at 17:00 pm on 19.06 .2019 , then $9.9 \mathrm{~W} / \mathrm{m}^{2}$. $\mathrm{K}$ at $17: 00 \mathrm{pm}$ on 18.06 .2019 , and $2 \mathrm{~W} / \mathrm{m}^{2}$. $\mathrm{K}$ at 18:00 pm on 17.06.2019. Therefore, a noticeable improvement in the fresh water productivity from solar still has been observed with increasing solar radiation intensity, ambient temperature and decreasing relative humidity. The amount of production during a cloudy day was $287 \mathrm{ml} / \mathrm{m}^{2}, 620 \mathrm{ml} / \mathrm{m}^{2}$ for a partial cloudy day and $950 \mathrm{ml} / \mathrm{m}^{2}$ during a sunny day.
\end{abstract}

\section{INTRODUCTION}

By comparing solar energy with other energies, solar energy is clean, available, cheap and most importantly environmentally friendly [1]. Getting fresh drinking-water is very important to health, a basic populace's right and a component of an effective policy of populaces' health protection. Furthermore, potable water is important as health and the development affair at local, national and regional levels [2]. The freshwater scarcity is the main problem in the world which worsens with time [3]. Solar distillation is one of the most important applications which used to produce fresh water especially in the rural and remote areas, the latter uses simple techniques to convert salt or water to the freshwater, without fuel consumption [4]. Solar distillation technology, such as the mechanism of rain in nature, the solar radiation heats and evaporates basin water within solar still and separated it from dirt, salt and impurities and anything else, when water vapour temperature reduced, the latter returns to the liquid phase [5]. There are several conditions that have various affect the production of freshwater from solar stills such as operational, design and environmental conditions. The environmental conditions are difficult to control on it such as humidity, solar radiation intensity, ambient air temperature [610]. Several researchers have studied the effect of environmental conditions on the performance and productivity of solar distillers. Recent study [11] reported that the solar still productivity increases with increasing solar radiation intensity, ambient temperature and wind speed. Another study [12] found that the rate of distillation increases with increasing solar radiation and ambient temperature, however, the higher wind speed leads to decrease the condensation and evaporation processes. The objective of the current study is to investigate the productivity of a modified single-slope solar distillation under variable climatic conditions according to the climatic conditions of Yekaterinburg city / Russia.

\section{GOVERNING EQUATIONS}

According to first law of thermodynamic the thermal analysis for the new design considering the energy balance for main parts are present as follows:

\subsection{Plexiglas cover, pg}

The summation of energy absorbed by Plexiglas cover from solar radiation and water basin by convection, evaporation and radiation are equal to the rate of energy stored by Plexiglas cover plus the rate of energy transferred from the Plexiglas cover to the atmosphere as follows [13]:

$$
\begin{aligned}
I(t) \times \alpha_{g} \times A_{g}+ & Q_{c, w-g}+Q_{r, w-g}+Q_{e, w-g} \\
& =m_{g} c_{p_{g}} \cdot \frac{d T_{g}}{d t}+Q_{r, g-s}+Q_{c, g-a}
\end{aligned}
$$

where, $I(t)$ intensity of solar radiation $\mathrm{W} / \mathrm{m}^{2}, \alpha_{\mathrm{pg}}$ is fractional solar flux absorbed by the glass cover, Apg is the Plexiglas cover area $\mathrm{m}^{2}\left(Q_{c, w-p g}\right.$ is the water- Plexiglas convection heat transfer $(W), Q_{r, w-p g}$ is the water-Plexiglas radiation heat transfer $(W), Q_{e, w-p g}$ is the water- Plexiglas evaporation heat 
transfer $(W), \mathrm{m}_{\mathrm{g}}$ is the mass of Plexiglas cover $(\mathrm{kg}), c_{p_{g}}$ is the heat capacity of the Plexiglas cover $(J / k g . K), d T_{p g}$ is the temperature difference between water and Plexiglas surfaces $\left({ }^{\circ} \mathrm{C}\right), Q_{r, p g-s}$ is the rate of heat transferred by radiation from Plexiglass cover surface to the atmosphere $(W)$ and $Q_{c, p g-a}$ is the rate of heat transferred by convection from Plexiglass cover surface to the atmosphere $(W)$.

$$
Q_{c, w-g i}=h_{c, w-p g} \times A_{w} \times\left(T_{w}-T_{p g}\right)
$$

where, $A_{w}$ is the surface area of basin water $\left(m^{2}\right), T_{w}$ is the basin water temperature $\left({ }^{\circ} \mathrm{C}\right), T_{p g}$ is the Plexiglas cover temperature $\left({ }^{\circ} \mathrm{C}\right), h_{c, w-g i}$ is coefficient of heat transfer by convection between the Plexiglas cover and the water, which is derived according to Dunkel's relation [14].

$$
\begin{aligned}
h_{c, w-g i}=0.884 \times & {\left[\left(T_{w}-T_{p g}\right)\right.} \\
+ & \left.\frac{\left(P_{w}-P_{p g}\right) \times T_{w}}{\left(268900-P_{w}\right)}\right]^{1 / 3}
\end{aligned}
$$

where, $P_{w}$ is the vapor pressure at water temperature, $P_{p g}$ is the vapor at the glass temperature:

$$
\begin{gathered}
P_{w}=\exp \left(25.317-\frac{5144}{T_{w}+273.15}\right) \\
P_{p g}=\exp \left(25.317-\frac{5144}{T_{p g+273.15}}\right) \\
Q_{e, w-g l}=\dot{m}_{w} \times h_{f g}=h_{e, w-p g} A_{w}\left(T_{w}-T_{p g}\right)
\end{gathered}
$$

where, $h_{e, w-g i}$ is coefficient of heat transfer by evaporation between the Plexiglas cover and the water [14].

$$
\begin{gathered}
h_{f g}=2.4935 \times 10^{6}\left(1-9.4779 \times 10^{-4} \cdot T_{w}\right. \\
+1.3132 \times 10^{-7} \cdot T^{2} \\
\left.-4.7974 \times 10^{-9} \cdot T_{w}{ }^{3}\right) \\
h_{e, w-p g}=16.276 \times 10^{-3} h_{c, w-p g} \times \frac{\left(P_{w}-P_{p g}\right)}{\left(T_{w}-T_{p g}\right)} \\
Q_{r, w-p g}=\varepsilon_{e f f} \cdot \sigma \cdot A_{w}\left[\left(T_{w}+273.15\right)^{4}\right. \\
\left.-\left(T_{p g}+273.15\right)^{4}\right]
\end{gathered}
$$

$\varepsilon_{e f f}$ is the effective emissivity of water surface to the glass cover [15]:

$$
\varepsilon_{e f f}=\frac{1}{\left(\frac{1}{\varepsilon_{w}}+\frac{1}{\varepsilon_{g}}-1\right)}
$$

where, the values of the constants will be $\varepsilon_{w}=0.96, \varepsilon_{p g}=$ 0.88

$\sigma$ is the Stefan Boltzmann's constant taken as $5.67 \times$ $10^{-8} \mathrm{~W} / \mathrm{m}^{2} \mathrm{k}^{4}$

$h_{r, w-p g}$ is coefficient of heat transfer by radiation between the Plexiglas cover and the water as follows [16]:

$$
\begin{aligned}
h_{r, w-p g}=\varepsilon_{e f f} \sigma & {\left[\left(T_{w}+273.15\right)^{2}\right.} \\
& \left.-\left(T_{p g}+273.15\right)^{2}\right] \\
& \times\left[T_{w}+T_{p g}+546\right]
\end{aligned}
$$

The Plexiglas-sky radiative heat transfer

$$
Q_{r, g-s}=h_{r, g-s} \times A_{g} \times\left[T_{g o}-T_{a}\right]
$$

where, the Plexiglas-sky radiative heat transfer coefficient, $h_{r, g-s}$ is [16]:

$$
h_{r, g-s}=\varepsilon_{g} \times \sigma \times\left[\frac{T_{p g}^{4}-T_{s k y}^{4}}{T_{p g}-T_{a}}\right]
$$

The sky temperature is:

$$
T_{s k y}=T_{a}-6.0
$$

The Plexiglas-ambient convection heat transfer

$$
\begin{gathered}
Q_{c, p g-s k y}=h_{c, g-s} \times A_{g} \times\left[T_{p g}-T_{a}\right] \\
h_{c, p g-s k y}=5.7+2.8 \mathrm{~V} \text { for } V>5 \mathrm{~m} / \mathrm{s} \\
h_{c, p g-s k y}=2.8+3 \mathrm{~V} \text { for } V \leq 5 \mathrm{~m} / \mathrm{s}
\end{gathered}
$$

\subsection{Basin liner, b}

The equation for the basin liner energy balance is:

$$
\begin{aligned}
I_{S}(t) \times A_{b} \times \alpha_{b} \times & \tau_{g} \times \tau_{w} \\
& =m_{b} c_{p_{b}} \cdot \frac{d T_{b}}{d t}+Q_{C, b-w} \\
& +Q_{\text {Loss }, b-a}
\end{aligned}
$$

where,

$A_{b}$ is the basin surface area $\left(\mathrm{m}^{2}\right), \alpha_{b}$ is fractional solar flux absorbed by the basin plate, $\tau_{g}$ is the Plexiglas transmissivity, $\tau_{w}$ is the water transmissivity, $m_{b}$ is the mass of basin $\left(k_{g}\right), c_{p_{b}}$ is the specific heat of basin plate $(J / k g . K), Q_{C, b-w}$ is the heat transfer from basin liner to the water $(W), Q_{\text {Loss }, b-a}$ is the total heat loss from the basin liner to the ambient air (W).

$$
Q_{C, b-w}=h_{c, b-w} \times A_{b} \times\left(T_{b}-T_{w}\right)
$$

where, $h_{c, b-w}$ is the coefficient heat transfer by convection from basin liner to the water $\left(W / m^{2} . K\right)$

$T_{b}$ is the basin liner temperature $\left({ }^{\circ} \mathrm{C}\right)$ [17].

$$
h_{c, b-w}=\frac{\overline{N u_{L}} \cdot K_{w}}{L_{b}}
$$

where,

$$
\left\{\begin{array}{ll}
N u_{L}=0.54 R a_{L}^{1 / 4} & \left(10^{4} \leq R a_{L} \leq 10^{7}\right. \\
N u_{L}=0.15 R a_{L}^{1 / 3} & \left(10^{7} \leq R a_{L} \leq 10^{11}\right.
\end{array}\right\}
$$

$K_{w}$ water thermal conductivity $(W / m . K), L_{b}$ is the ratio of surface area to perimeter of the basin plate represents $(\mathrm{m}), R_{A}$ is Rayleigh number 


$$
R_{a}=\frac{g \times \beta_{w} \times L_{b}{ }^{3} \times\left(T_{b}-T_{w}\right)}{v_{w} \times \alpha_{w}}
$$

$\beta_{w}$ is the coefficient of thermal expansion is given by: where, $v_{w}, \alpha_{w}$, and $\beta_{w}$ are the kinematic viscosity $\left(\mathrm{m}^{2} / \mathrm{s}\right)$, thermal diffusivity $\alpha_{w}=\frac{k_{w}}{\rho_{w} \cdot c p_{w}}\left(\frac{m^{2}}{s}\right)$, and the thermal expansion coefficient of basin water $\beta_{w}=\frac{1}{T}\left(\frac{1}{K}\right)$.

$Q_{\text {Loss }}$ the loss heat transfer between the basin plate and ambient air $(W)$.

$$
Q_{\text {Loss }}=U_{b}\left(A_{b}+A_{\text {sides }}\right) \times\left(T_{b}-T_{a}\right)
$$

The total loss of heat coefficient in the basin metal plate and other sides to the environment as following equation

$$
U_{b}=\left[\frac{L_{i}}{K_{i}}+\frac{1}{h_{t, b-a}}\right]^{-1}
$$

where, $L_{i}$ is insulation thickness $(0.18 \mathrm{~cm})$ and $k_{i}$ represent the thermal conductivity of insulation $(w / m . k), A_{b}$ bottom basin liner area $\left(0.432 \mathrm{~m}^{2}\right)$ and $A_{\text {sides }}$ sides basin liner area $\left(0.28 \mathrm{~m}^{2}\right), h_{t, b-a}$ is the total heat transfer coefficient from basin liner to the ambient air $(W / m . k)$.

$$
h_{t, b-a}=5.7+3.8 \times V_{a}
$$

where, $V_{a}$ is the wind speed $(\mathrm{m} / \mathrm{s})$

The hourly cumulative distillate water output, $m_{w}$, for the conventional solar water distillery in $\left(\mathrm{kg} / \mathrm{m}^{2} . \mathrm{hr}\right)$ was obtained by the evaporation heat transfer coefficient $h_{e, w-g i}$, multiplied by the difference between basin water temperature $T_{w}\left({ }^{\circ} \mathrm{C}\right)$ and inner glass cover temperature $T_{g i}\left({ }^{\circ} \mathrm{C}\right)$ and 3600 , hence the results were divided by the average latent heat $h_{f g}$ at average basin water temperature[18]:

$$
m_{w}=\frac{h_{e, w-g i} \times A_{b} \times\left(T_{w}-T_{g i}\right) \times 3600}{h_{f g}}
$$

where, $A_{b}$ is the basin plate area as $\left(0.432 \mathrm{~m}^{2}\right)$ and $h_{f g}$ is the average latent heat in $(J / k g)$ :

Daily distillate per unit area;

$$
\dot{m}_{w_{d}}=\sum_{i=1}^{24} \dot{m}_{w}
$$

\subsection{Basin water, w}

The energy balance in the water of basin is equal to summation of the energy of solar radiation and the thermal energy absorbed by convection minus the thermal energy stored in the basin water and thermal energy transferred by convection, evaporation and radiation to the inner side of the cover glass

$$
\begin{aligned}
I_{s}(t) \times A_{w} \times \alpha_{w} & \times \tau_{g}+Q_{c, b-w} \\
& =m_{w} c_{w}\left(\frac{d t_{w}}{d t}\right)+Q_{c, w-g} \\
& +Q_{r, w-g}+Q_{e, w-g}+Q_{f w}
\end{aligned}
$$

$Q_{f w}:$ Heat taken by feed water

$$
Q_{f w}=m_{e} \cdot C_{p w} \cdot\left(T_{w}-T_{a}\right)
$$

\section{METHODOLOGY OF EXPERIMENTAL}

\subsection{Fabrication of solar still}

Single-basin single-slope solar stills are the cheapest and most widespread of all currently available solar distillation systems, its main problem is low productivity. Therefore, in the current study a simple and inexpensive solar distillation system has been designed. Figure 1 shows a photograph and schematic diagram of the experimental setup of a single slope solar still with dimensions of $100 \times 50 \times 61.8 \times 26.6 \mathrm{~cm}$ consists of wooden frame of dimensions $100 \times 50 \times 10 \mathrm{~cm}$ and thickness of $0.18 \mathrm{~cm}$. A plexiglass cover $(0.3 \mathrm{~cm})$ of dimentions $100 \times 50 \times 50 \times 14.8 \mathrm{~cm}$ fixed on the wooden frame with single inclined to the horizontal (35 degrees). In order to form a transparent cover from all sides except the bottom and back the frame was opened in order to install the cover on both wooden frame and MDF wooden board $100 \times 60 \times 0.18 \mathrm{~cm}$ in the back side of solar still. The water basin with a dimensions of $94 \times 46 \times 10 \times 0.08 \mathrm{~cm}$ has been coated with black colour to absorb maximum amount of solar radiation, the basin was installed on the base solar still with dimensions $100 \times 50 \times 0.18 \mathrm{~cm}$, and then the solar still was closed by installing the top cover of the solar still. The inner surface of still covered by Aluminium foil with $0.03 \mathrm{~cm}$ thickness. Plexiglass is fixed on the wooden frame by using an Aluminium channel to collect condensed water droplets through the plexiglass. The condensed water passed through the Aluminium channel to a gradient plastic cylinder installed at the bottom of solar still. All parts are fixed by silicone glue to prevent air leakage. A water tank is connected to the solar still via pipes to feed the solar still with seawater. The level of salt-water inside has been controlled by using a mechanical floater, in order to clean basin liner a hole was made at the bottom of the water basin and a globe valve was installed to drain brackish water.

\subsection{Measurement method}

Secure digital (SD) card data logger 4 channel Kthermocouple device (model 88598) has been used to measure the temperatures at various places in the solar still such as basin liner (1), basin water (2), plexiglass cover surfaces (3) and vapour temperature within solar still (4). All thermocouples have been calibrated between $\left(100-0^{\circ} \mathrm{C}\right)$. To measure the ambient temperature and relative humidity also, a humidity and temperature meter (GM1362) and thermometer mercurial have been used and placed at a height of $1 \mathrm{~m}$ from the surface level in the shade to protect it from the sun radiation or lights (5). A solar power meter device (TENMARS TM-207) units used to measure the solar radiation intensity in $W / \mathrm{m}^{2}$ (6). Anemometer device (ut363) has been used to measure the wind speed (7) as shown in Figure 2. 

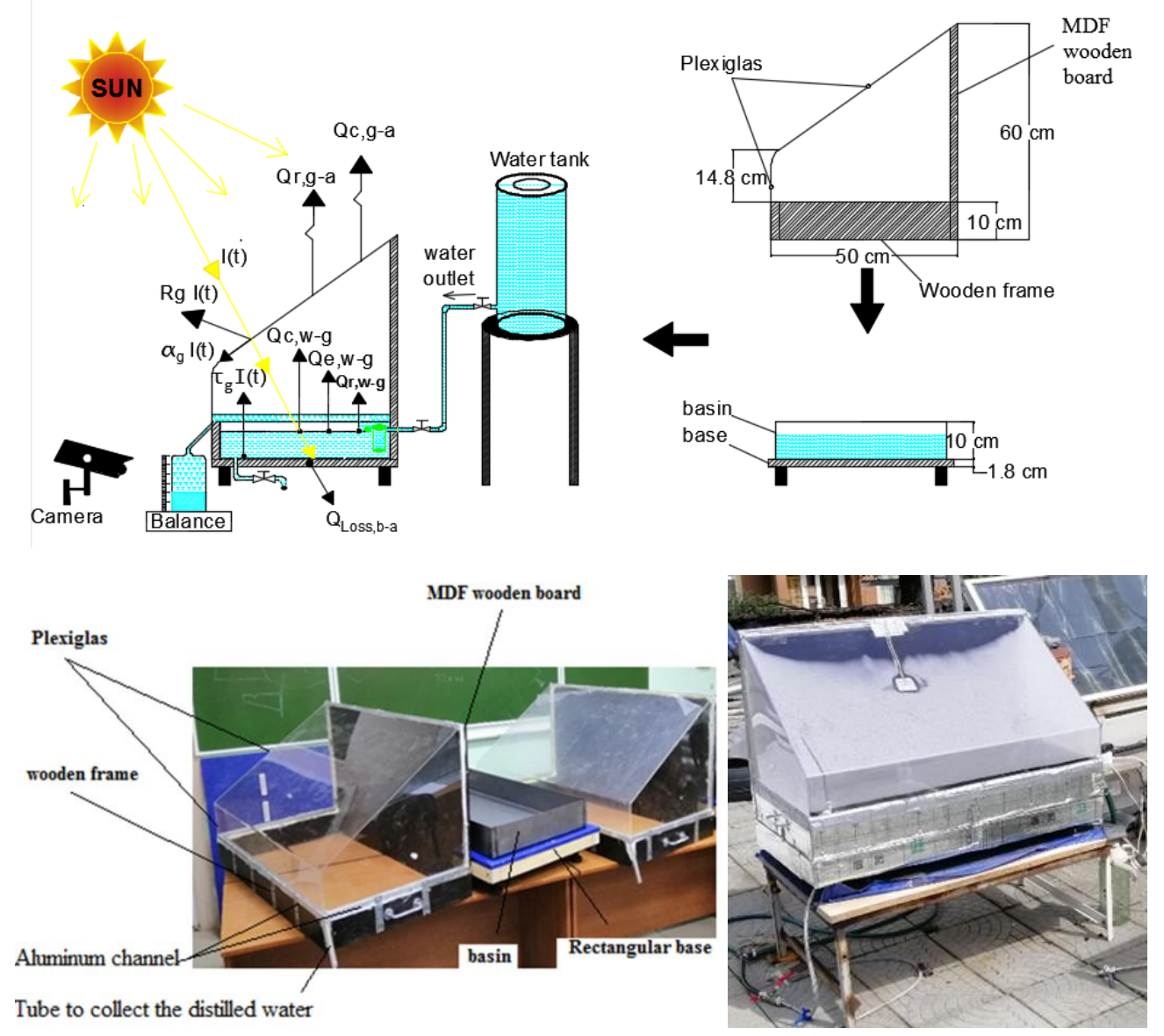

Figure 1. Photograph and schematic diagram of the experimental setup of a single slope solar still

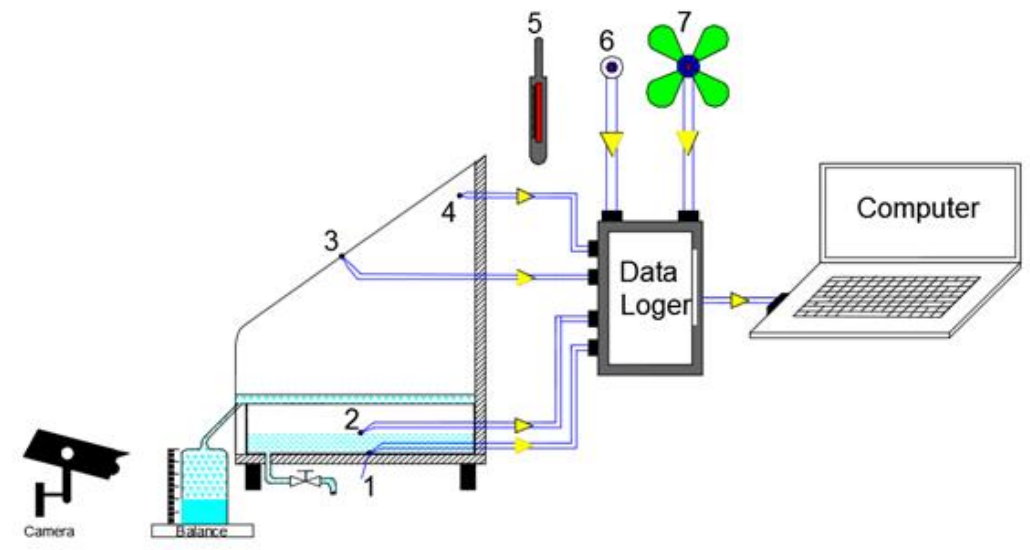

Figure 2. Schematic diagram of a measurement system

Table 1 illustrated the error ratio which includes lists of error transaction measurements that have been verified for several experimental tests, the error ratio was calculated by using following relations:

Table 1. Accuracy and error ratio of the measuring devices used in the current study

\begin{tabular}{ccc}
\hline Device & Accuracy & Error\% \\
\hline SD data logger & $\pm 0.3 \% \mathrm{rdg}$ & $0.1 \%$ \\
Thermometer Mercurial $/ 0-100^{\circ} \mathrm{C}$ & -200 to $1370^{\circ} \mathrm{C}$ & $0.5 \%$ \\
$98 \%$ Temperature -10 to $50^{\circ} \mathrm{C}$ & $1{ }^{\circ} \mathrm{C}$ & $0.1 \% \mathrm{~T}$ \\
Humidity and temperature meter & $\left.0.1^{\circ} \mathrm{C}\right)$ & $\% \mathrm{RH}$ \\
Solar power meter device (TENMARS TM-207)/ $0-200 \mathrm{w} / \mathrm{m}^{2}$ & $\pm 10 \mathrm{~W} / \mathrm{m}^{2}$ & \pm 0.38 \\
Anemometer device (ut363)/ $0-25 \mathrm{~m} / \mathrm{s}$ & $\pm 5 \% \mathrm{rdg}+0.5^{\circ} \mathrm{C}$ & $2.5 \%$ \\
\hline
\end{tabular}




$$
\begin{gathered}
\text { Error } \%=\left(\frac{S . E}{X^{\prime}}\right) \times 100 \\
S . E=\frac{S}{\sqrt{n}} \\
S=\sqrt{\frac{\sum_{i-1}^{n}\left(X_{i}-X^{\prime}\right)^{2}}{n-1}} \\
X^{\prime}=\frac{\sum_{i=1}^{n} X_{i}}{n}
\end{gathered}
$$

where, S.E is the standard error, $\mathrm{S}$ is the standard deviation, $X_{i}$ is the real measured values, $X^{\prime}$ is the average of real measured values and $\mathrm{n}$ is the number of measurements.

\subsection{Experimental procedures}

The experimental tests were carried out at Ural Federal University of Yekaterinburg city/Russia in June 2019 during three typical days, and at different environmental conditions, cloudy, partly cloudy and sunny day. Current study consisted of two stages, first stage is the primer testing on the system, in order to evaluate performance and the possibility of the amendment in the designs in order to reach the best case. Second stage is an actual test of the system, which included the calculation of the average daily productivity of solar stills every one hour. The results have been compared at different environmental conditions, all tests were started at 8:00 am and continued until 20:00 pm (12 hours), the total number of tests was 12 .

\section{ESTIMATE THE COST OF FRESHWATER PRODUCTIVITY}

The production cost of one liter of freshwater for a perfect day 19.06.2019 at the highest productivity improvement with a rotational speed of $0.5 \mathrm{rpm}$ estimated as follows:

The total cost of the fabrication of solar still $\mathrm{C}$ is equal to summing the fixed costs $\mathrm{F}$ and variable costs $\mathrm{V}$ [18]:

$$
C=F+V
$$

where,

$$
V=n \times 0.1 \times F
$$

Suppose the variable cost V is $0.05 \mathrm{~F}$ per year as a cost of periodic maintenance.

$\mathrm{n}$ : Life expectancy for both solar stills are 10 years.

Then the total cost for conventional solar still Table 2.

$$
C=62+10 \times 0.05 \times 62=93 \$
$$

The daily productivity from solar collector per unit area $0.432 \mathrm{~m}^{2}$ was $0.95 \mathrm{~L} / \mathrm{m}^{2}$, if assuming the solar still operating 180 days in the year, therefore the total annual productivity during the work period 10 years for solar still is $1710 \mathrm{~L}$. So, the cost of production of one littler of freshwater from solar still is $93 / 1710=0.054 \$$.
Table 2. Fabrication fixed cost for single slope solar still

\begin{tabular}{ccc}
\hline Unit & Quality & Cost \\
\hline MDF wooden board, $1.8 \mathrm{~cm}$ & $2 \mathrm{~m}^{2}$ & 14 \\
Plexiglas cover 0.3 cm thickness & $1.2 \mathrm{~m}^{2}$ & 15 \\
Galvanized iron sheet basin, $0.08 \mathrm{~cm}$ & $1.5 \mathrm{~m}^{2}$ & 11 \\
Spray paint heat-resistant & 2 pieces & 3 \\
A mechanical float & 1 piece & 1 \\
Heat-resistant silicone glue & 2 pieces & 3 \\
Saltwater feeding system & - & 15 \\
Total cost & - & 62 \\
\hline
\end{tabular}

\section{RESULTS AND DISCUSSION}

The current study has been used program (Origin pro 2018) to illustrate the effects of environment parameters on the performance and productivity of new design single slope solar still. Experimental weather data has been studied in detail, which included solar radiation density, relative humidity and ambient temperature. Figure 3 shows the experimental results taken for three typical days in Jun 2019, at different environmental conditions. It was obvious that the environment parameters depended strongly on the weather which is always variable and unstable in the Yekaterinburg city/Russia. Rarely the weather was clear and without clouds during the testing days. The weather data experimental study includes solar radiation density and relative humidity, ambient temperature.

Early in the morning times, intensity of solar radiation and ambient temperature are relatively low while the relative humidity is relatively high. When it is approach noon, between 13:00 pm and 15:00 pm, the rate of solar radiation increases, and then falls again in the afternoon. After a period of solar radiation reach to the ground area, it begins to transfer heat energy to the surrounding areas, so the maximum ambient temperature occurs around 14:00-15:00 pm and at the same time, the lowest value of relative humidity. Figure 3 (a) illustrate the relation between the time for each hour and solar radiation intensity, ambient and relative humidity for three a perfect day. It is observed that the highest solar radiation intensity was $1039 \mathrm{~W} / \mathrm{m}^{2}$ at 14:00 $\mathrm{pm}$, which recorded during a sunny day in $17 / 06 / 2019$, then $900 \mathrm{~W} / \mathrm{m}^{2}$ at $16: 00 \mathrm{pm}$ during a partial cloudy day in 18/06/2019 and the lowest value was $478 \mathrm{~W} / \mathrm{m} 2$ at 13:00 pm during a cloudy day in 19/06/ 2019, and the rate of solar radiation during 12 hours from 08:00 am to $20: 00 \mathrm{pm}$ was $711.69 \mathrm{~W} / \mathrm{m}^{2}, 438.69 \mathrm{~W} / \mathrm{m}^{2}$ and $295.38 \mathrm{~W} / \mathrm{m}^{2}$, respectively. The relation between the solar radiation and the ambient temperature proportional directly, and indirectly with relative humidity which means that when the intensity of solar radiation increases. The ambient temperature also increases while relative humidity decreases and vice versa. Figure 3 (b) shows that the largest value of the ambient temperatures was recorded $23.3^{\circ} \mathrm{C}$ at $15: 00 \mathrm{pm}$ in 19.06 .2019 , and $17.8^{\circ} \mathrm{C}$ at $15: 00 \mathrm{pm}$ in 18.06.2019, while recorded at $15: 00 \mathrm{pm} 15.8^{\circ} \mathrm{C}$ in 17.06.2019. While the relative humidity values at 15:00 was $35.2 \%, 39 \%$ and $42.8 \%$, respectively as shown in Figure 3 (c).

Figure 4 shows that the basin water temperature is affected by the climatic conditions. It can observe that the basin water temperatures increase with increasing solar radiation intensity and ambient temperature which corresponds to in the finding previous study [19]. The highest value of basin water temperature was recorded in 19.06.2019, which reached 48.6 at 15:00 pm, followed by day 18.06.2019 which recorded 39.9 at 16:00 pm, while on day 17.06.2019 it reached 30.5 at 16:00 $\mathrm{pm}$. The mechanism of heat transfer and mass transfer within 
the solar still occurs in three forms, convection, radiation and evaporation. These mechanisms depended on environmental parameters. It was observed that the values of the heat transfer coefficient by convection, radiation and evaporation has been increased with increasing solar radiation intensity and ambient temperature and decreased the relative humidity. The heat transfer coefficients have been gradually increasing from the early morning after 08:00 am and reached the highest value at the noon and decreases afternoon gradually to reach the lowest value at 20:00 pm.

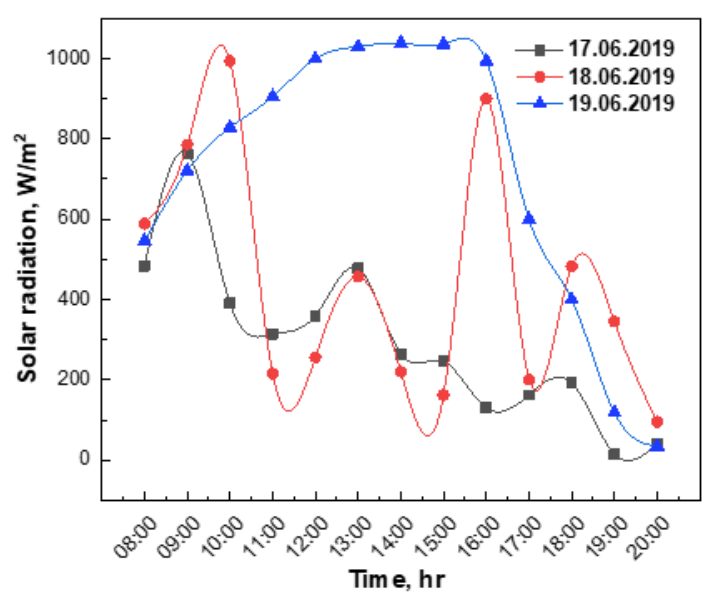

(a)

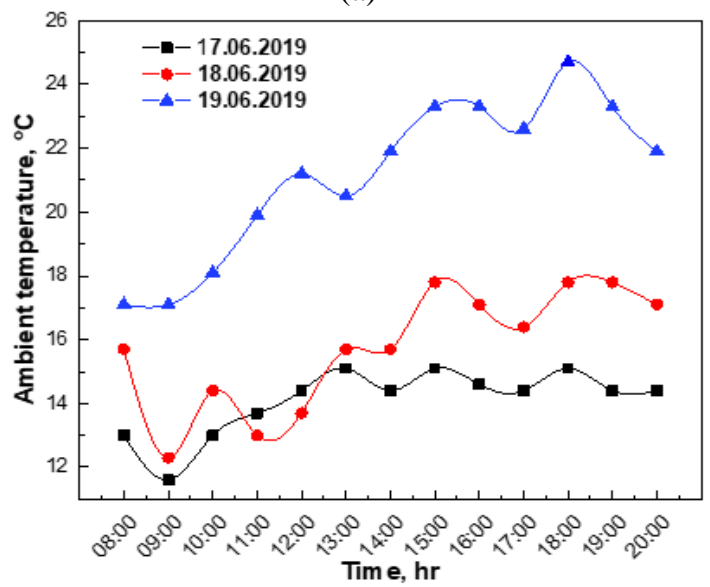

(b)

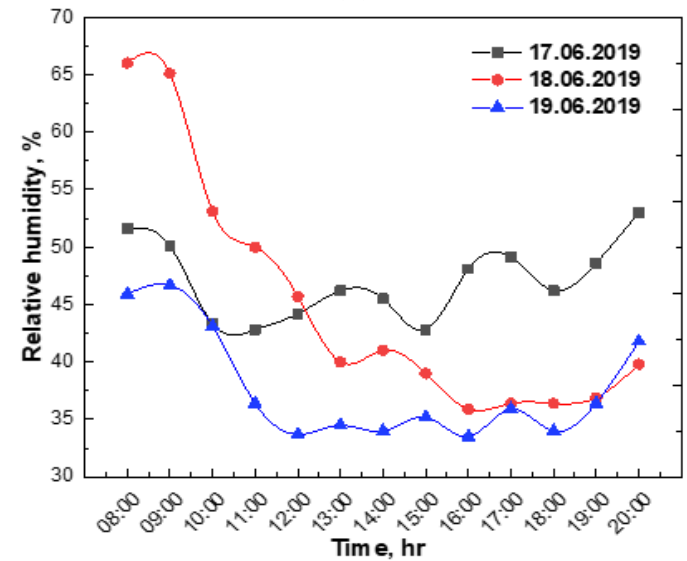

(c)

Figure 3. Relation between the time for each hour and (a) solar radiation, (b) ambient temperature and (c) relative humidity for three a perfect day in June 2019

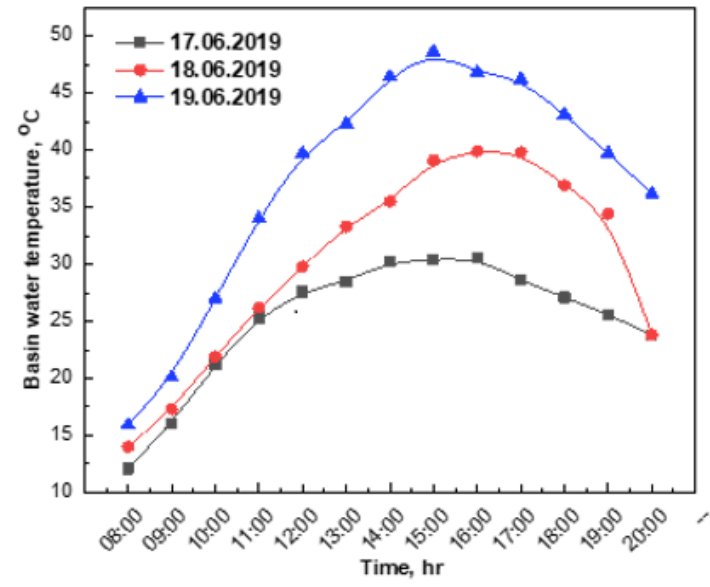

Figure 4. The basin water temperatures during three a perfect day in June 2019

Figure $5(\mathrm{a}, \mathrm{b}$, and $\mathrm{c})$ illustrate the relation between heat transfers coefficients (radiation, convection and evaporation, respectively) and time for each hour during three perfect days. It has been observed that, at various environment conditions the rate of coefficient of heat transfer by evaporation is greater than that by convection and radiation, which depended mainly on the rate of solar radiation and the ambient temperature. The largest value of coefficient of heat transfer by evaporation was $12.1 \mathrm{~W} / \mathrm{m}^{2} . k$ at 17:00 pm on 19.06.2019, then $9.9 \mathrm{~W} / \mathrm{m}^{2} . k$ at 17:00 on 18.06.2019, and on 17.06.2019 it was $2 \mathrm{~W} / \mathrm{m}^{2} . k$ at 18:00 pm. The reason for the improvement ratio in the evaporative heat transfer coefficient in 19.06. 2019 was due to increase the solar radiation and ambient temperature in comparison with the rest of the two days (partially cloudy and cloudy), so, the heat transfer mechanism within the solar still depends on the temperature difference between the basin water and a plexiglass cover. Therefore, when the value of solar radiation and the ambient temperature has been increased, the basin water temperature increased, and the rate of heat transferred by evaporation, convection, and radiation increased too. It was also observed from Figure 5 (d) that the total heat transfer coefficient for day 19 June was the largest value, then on day 18 June and the lowest on day 17 June 2019 , and this confirms the fact of effected the environmental conditions on the heat transfer coefficients within the solar still.

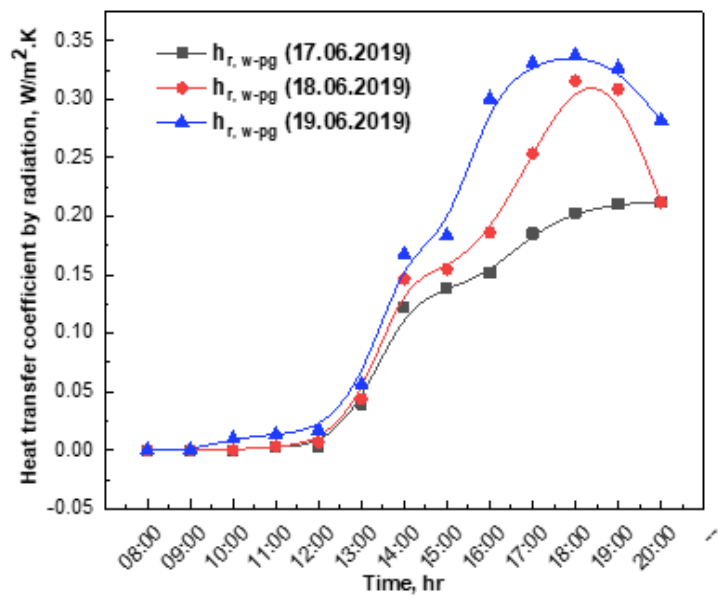

(a) 


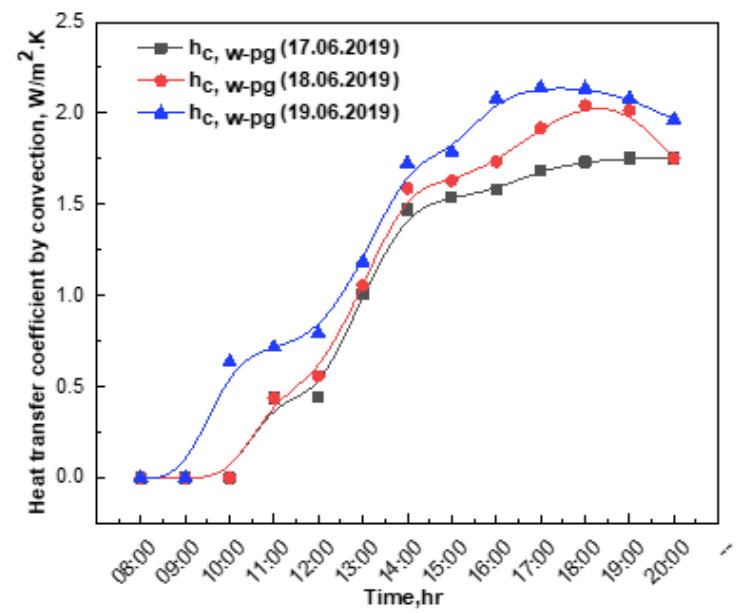

(b)

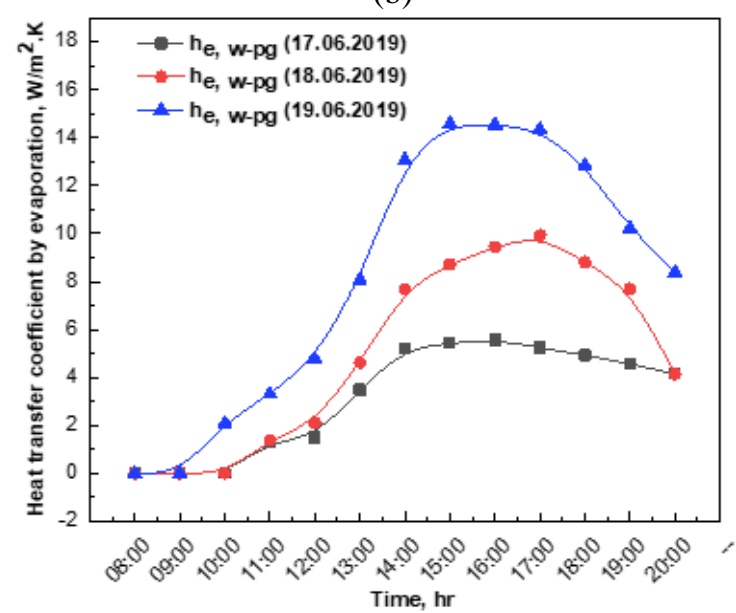

(c)

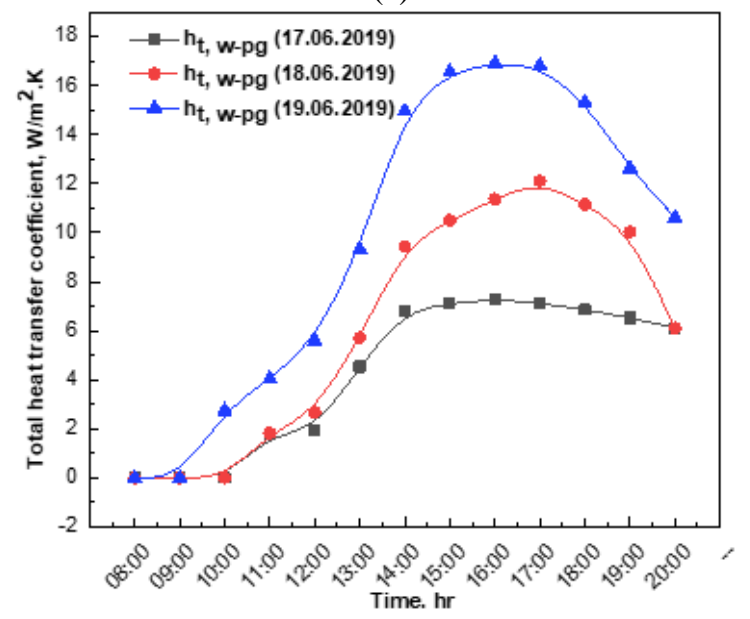

(d)

Figure 5. Coefficients heat transfer values between basin water and Plexiglas cover during three a perfect day in June 2019

Figure 6 illustrates the amount of freshwater productivity per each hour during three a typical day. It is found that the productivity of the solar distillery is directly affected by the surrounding environmental conditions. The largest amount freshwater productivity was recorded in the sunny day 19.06.2019 and at high ambient temperature and low relative humidity, which was $950 \mathrm{ml} / \mathrm{m}^{2}$ during 12 hours from 08:00 am to 20:00 pm, in a partial cloudy day 18.06.2019 it was reach to $620 \mathrm{ml} / \mathrm{m}^{2}$ while the lowest rate it was during a cloudy day 17.06 .2019 amounted to $285 \mathrm{ml} / \mathrm{m}^{2}$. The reason for the differences in the average daily production for three days is that the productivity of solar still is greatly affected by the intensity of solar radiation and the ambient temperature, which is similar to those found in the literature [20].

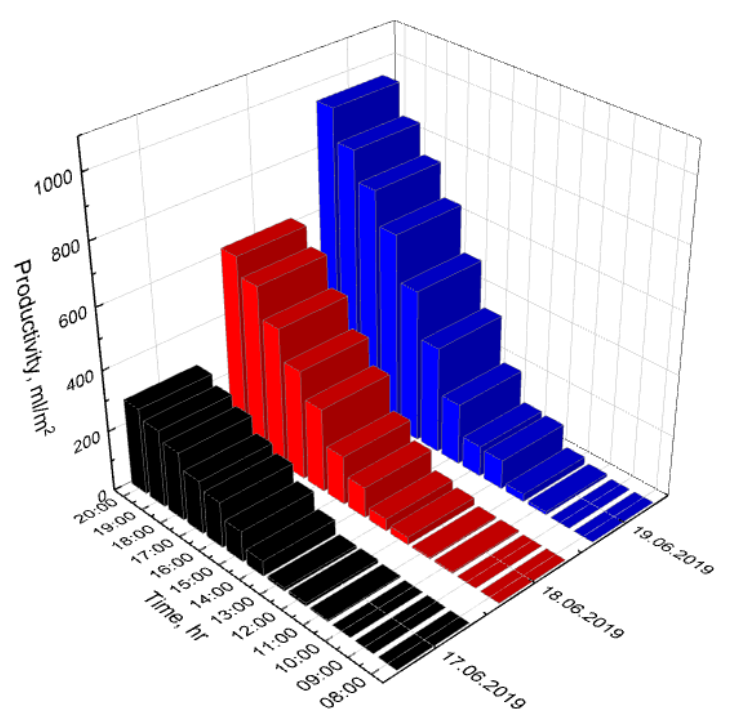

Figure 6. The fresh water productivity values during three a perfect day in June 2019

\section{CONCLUSION}

From the results of the present study, the following conclusion has been addressed:

- Environmental conditions have noticeable impact on the daily production rate of the improved solar distillation; the highest rate of freshwater productivity was $950 \mathrm{ml} / \mathrm{m}^{2}$ in 19 June 2019.

- Increasing the solar radiation intensity with low relative humidity leads to an increase in the productivity of solar still.

- The process of condensation is occurring due to the temperature's differences between the water and glass cover (an increase of temperatures differences, that's lead to increase of condensate process).

Finally, the estimated production cost of one litter of freshwater from the new design single slope conventional solar still is $0.054 \$$ according to the harsh weather conditions of Russia, this cost is considered relatively acceptable if it is compared with the cost of production in regions with high levels of solar radiation intensity and ambient air temperature.

\section{REFERENCES}

[1] Kaushal, A., Varun. (2010). Solar stills: A review. Renewable and Sustainable Energy Reviews, 14(1): 446453. https://doi.org/10.1016/j.rser.2009.05.011

[2] Ghaffour, N., Bundschuh, J., Mahmoudi, H., Goosen, M.F.A. (2015). Renewable energy-driven desalination technologies: A comprehensive review on challenges and potential applications of integrated systems. Desalination, 356: 94-114. https://doi.org/10.1016/j.desal.2014.10.024

[3] Manokar, A.M., Winston, D.P., Kabeel, A.E. (2018). Sustainable fresh water and power production by integrating PV panel in inclined solar still Sustainable 
fresh water and power production by integrating PV panel in inclined solar still. Journal of Cleaner Production, 172:

2711-2719. https://doi.org/10.1016/j.jclepro.2017.11.140

[4] Garcia-rodriguez, L., Palmero-marreroa, A.I., Gbmezcamachob, C. (2002). Comparison of solar thermal technologies for applications in seawater desalination. Desalination, 142(2): $135-142$ https://doi.org/10.1016/S0011-9164(01)00432-5

[5] Panchal, H., Kumar, K., Israr, M., Thakar, N. (2019). Various techniques to enhance distillate output of tubular solar still: A review. Groundwater for Sustainable Development, 9: 100268 https://doi.org/10.1016/j.gsd.2019.100268

[6] Abujazar, M.S.S., Fatihah, S., Rakmi, A.R., Shahrom, M.Z. (2016). The effects of design parameters on productivity performance of a solar still for seawater desalination: A review. Desalination, 385: 178-193. https://doi.org/10.1016/j.desal.2016.02.025

[7] Al-Hinai, H., Al-Nassri, M.S., Jubran, B.A. (2002). Effect of climatic, design and operational parameters on the yield of a simple solar still. Energy Conversion and Management, 43: 1639-1650.

[8] Ithape, P.K., Nadgire, A.R. (2017). climatic and design parameters effects on the productivity of climatic and design parameters effects on the productivity of solar stills: A review. International Journal of Current Engineering and Scientific Research (IJCESR), 4(7).

[9] Khalifa, A.J.N., Hamood, A.M. (2009). On the verification of the effect of water depth on the performance of basin type solar stills. Solar Energy, 83(8):

$1312-1321$. https://doi.org/10.1016/j.solener.2009.04.006

[10] Panchal, H.N., Patel, S. (2017). An extensive review on different design and climatic parameters to increase distillate output of solar still. Renewable and Sustainable Energy $\quad$ Reviews, $\quad 69$ : 750-758. https://doi.org/10.1016/j.rser.2016.09.001

[11] Trends, C. (2012). Effect of Climatic Parameters on the Performance of Different Designs of Stepped Type Solar Still. CiteSeer ${ }^{\mathrm{X}}$, 206-210.

[12] Taylor, P., Refalo, P., Ghirlando, R., Abela, S. (2014). The effect of climatic parameters on the heat transfer mechanisms in a solar distillation still. Heat Transfer Engineering, 35(16-17): $37-41$. https://doi.org/10.1080/01457632.2014.889479

[13] Velmurugan, V., Pandiarajan, S., Guruparan, P., Subramanian, L.H., Prabaharan, C.D., Srithar, K. (2009). Integrated performance of stepped and single basin solar stills with mini solar pond. DES, 249(3): 902-909. https://doi.org/10.1016/j.desal.2009.06.070

[14] Feilizadeh, M., Estahbanati, M.R.K., Ahsan, A., Jafarpur, K., Mersaghian, A. (2016). Effects of water and basin depths in single basin solar stills : An experimental and theoretical study. Universiti Putra Malaysia Institutional Repository, 122: 174-81. https://doi.org/10.1016/j.enconman.2016.05.048

[15] Abu-khader, M.M., Badran, O.O. (2007). Evaluating thermal performance of a single slope solar still. Heat and Mass Transfer, 43: 985-995.

[16] Abdullah, A.S., Essa, F.A., Omara, Z.M., Rashid, Y., Hadj-taieb, L., Abdelaziz, G.B., Kabeel, A.E. (2019). Rotating-drum solar still with enhanced evaporation and condensation techniques: Comprehensive study. Energy Conversion and Management, 199: 112024. https://doi.org/10.1016/j.enconman.2019.112024

[17] Nazari, S., Safarzadeh, H., Bahiraei, M. (2019). Experimental and analytical investigations of productivity, energy and exergy efficiency of a single slope solar still enhanced with thermoelectric channel and nanofluid. Renewable Energy, 135: 729-744. https://doi.org/10.1016/j.renene.2018.12.059

[18] Kumar, S., Tiwari, G.N. (1996). Estimation of convective mass transfer in solar distillation systems. Solar Energy, 57: 459-464. https://doi.org/10.1016/S0038-092X(96)00122-3

[19] Bello, A.D., Hashim, N.B., Ridza, M., Haniffah, M. (2017). Predicting impact of climate change on water temperature and dissolved oxygen in tropical rivers. Climate, 5(3): 58. https://doi.org/10.3390/cli5030058

[20] Nafey, A.S., Abdelkader, M., Abdelmotalip, A., Mabrouk, A.A. (2000). Parameters affecting solar still productivity. Energy Conversion and Management, 41(16): 1797-1809. https://doi.org/10.1016/S01968904(99)00188-0

\section{NOMENCLATURE}

$\begin{array}{ll}P C M & \text { Paraffin wax } \\ g & \text { Glass } \\ C & \text { Total cost of solar still } \\ F & \text { Fixed cost of solar still } \\ V & \text { Variable cost of solar still } \\ n & \text { Life expectancy for solar still } \\ S & \text { Standard deviation } \\ S E & \text { Standard error } \\ \alpha & \text { absorptivity } \\ R & \text { reflectivity } \\ \tau(t) & \text { Transmissivity } \\ T_{w} & \text { Water temperature } \\ T_{g} & \text { Glass cover temperature } \\ A_{b} & \text { Solar still basin area } \\ I(t) & \text { Total incident radiation } \\ h_{t, w-g} & \text { Total heat transfer coefficient between the glass } \\ h_{c, w-g} & \text { cover and the water } \\ h_{e, w-g} & \text { Coefficient of heat transfer by convection } \\ h_{r, w-g} & \text { between the glass cover and the water } \\ h_{r, g-a} & \text { between the glass cover and the water } \\ h_{f g} & \text { glass cover and water } \\ P_{w} & \text { Latent heat of } \\ P_{g} & \text { Vapour pressure at water temperature } \\ \dot{m}_{w} & \text { Vapour at the glass temperature } \\ m_{w} & \text { Mass transfer of water vapor } \\ \dot{m}_{w d} & \text { The amount of paily distion between } \\ \eta_{d} & \text { The daily efficiency of solar still } \\ & \end{array}$

